\title{
SPĒLĒJOT DIEVU: DIEVSPĒLES VIDEOSPĒLES ŽANRS UZ SPĒLĒTĀJU BALSTĨTAS PIEEJAS INTERPRETĀCIJĀ
}

Nikita Andrejevs

Mg. theol., LU Teologiijas fakultātes zinātniskais asistents

\section{Ievads}

Šī raksta mērksis ir izpētīt dievspēles (god-game) žanra videospēlēs prezentētās dievišǩ̄ibas koncepciju. Rakstā tiek analizēts reliǵisko jēdzienu lietojums aplūkoto videospēḷu mehānikas veidošanā uz spēlētāju orientētas pieejas interpretācijā. Uz spēlētāju orientēta pieeja vēršas pie spēlētājam pieejamām interaktīvām darbībām kā pētniecības objekta. Dievspēles žanra kontekstā ši pieeja sniedz ieskatu spēlētāja-dieva funkcijās; š̄ dieva veiksmes nosacījumos; attiecībās starp spēlētāju-dievu un viņa virtuālajiem sekotājiem. Šìs iezīmes veido gan atsevišķ spu ş̦̄u, gan žanra kopīgu dievišks̄ibas koncepciju. Reliǵijpētniecībā šĩ koncepcija tiek aplūkota kā daḷa no postmodernas populāras refleksijas par dievišksību, religiju un to nozīmi cilvēces vēsturē.

\section{Pieeja}

Videospēle (video game) ir "spēle, kas tiek spēlēta ar datora starpniecību neatkarīgi no tā izmēra". Savukārt, spēle ir "rotalıu darbības veids, kas tiek veikts iedomātās realitātes kontekstā, kurā dalībnieks vai dalībnieki mēǵina sasniegt vismaz vienu pieņemto, netriviālo mērksi, rīkojoties saskaņā ar noteikumiem”. Ernests Adamss (Ernest Adams) uzskata videospēles par daḷu no spēļu veseluma. Viņaprāt, videospēles no parastām spēlēm atšksir to spēja ietvert sevī citiem medijiem raksturīgas 
izklaidēšanas tehnikas. Tāpat videospēlē dators kontrolē spēles noteikumu ievērošanu un spēles gaitas ātrumu. Lìdz ar iedomātas pasaules grafisku attēlu tas lauj spēlētājiem dzil̄āk iegremdēties spēlē un redzēt to nevis kā pagaidu mākslīgu vidi ar pieņemtiem mērķiem, bet kā alternatīvu Visumu. ${ }^{1}$

1996. gadā videospēḷu žurnāls Next Generation definēja dievspēli kā "stratēgijas (strategy) žanra atzaru, kurā tiek pārvaldīta civilizācija vai maza cilts". ${ }^{2} 2006$. gadā videospēḷu žurnāls The Edge to definēja kā celtniecības un pārvaldes simulācijas (construction and managment simulation), reāllaika stratēgijas (real-time strategy) un mākslīgas dzīves simulācijas (artificial life simulation) žanru apvienojumu. Tajā spēlētājs pieņem kādas cilvēku grupas dievības lomu, tiem palīdzot. ${ }^{3}$ 2018. gadā dabaszinātñu vasaras izglītības nometñu centra iD Tech blogā publicētajā žanru klasifikācijā tā pieder pie dz̄̄ves simulācijas žanra. Tajā ietilpst arī spēles, kurām nav reliğiskas tematikas, bet kuras sniedz spēlētājam pārdabisku kontroli pār spēles tēliem un to apkārtni. ${ }^{4}$ Adamss raksta, ka žanru striktais nodalījums radies kopš laikiem, kad datoru jauda bija pārāk maza, lai piedāvātu ko vairāk par vienu spēles režīmu. Jaunākās spēles apvieno vairākus režīmus un izaicinājumus. Viņš definē videospēles žanru kā kategoriju, kas raksturo spēles pēc to izaicinājuma (challenge) tipa, neatkarīgi no spēles pasaules satura. ${ }^{5}$

Pats Adamss uzskata dievspēles par atsevišķu žanru, kaut arī tās izmanto elementus, kas ir raksturīgi minētiem spēḷu žanriem. Pirmkārt, tās atšksiras principiāli ar dievību kā spēlētāja lomu - iepretī pilsētas cēlējam vai valdniekam. ${ }^{6}$ Otrkārt,

1 Ernest Adams, Fundamentals of Game Design (Berkeley: New Riders, 2010), 3-22.

2 “The Next Generation 1996 Lexicon," Next Generation 15 (Mar. 1996): 34 .

${ }^{3} 50$ Greatest Game Design Innovations, https://web.archive.org/ web/20100924064303/http://www.next-gen.biz/features/50-greatest-game-design-innovations?page $=0 \% 2 \mathrm{C} 3$ (skatits 12.02.2018.)

${ }^{4}$ The Many Different Types of Video Games \& Their Subgenres, https://www.idtech.com/blog/different-types-of-video-game-genres (skatīts 12.02.2018.)

5 Adams, Fundamentals, 70.

6 Šajā rakstā tiks aplūkotas arī spēles, kuru galvenie tēli ir dievības, bet kas nepieder pie dievspēles žanra. 
tās atšksiras no stratēg̣ijas spēlēm ar netiešo kontroli pār spēlētāja vienībām (unit) - visbiežāk dievspēlēs dievība tikai veido apstākḷus saviem sekotājiem. ${ }^{7}$

Videospēḷu pētniecībā identificē divas pamata pieejas. Formālistu pieeja analizē pašu spēli, koncentrējoties uz spēles analīzi vai ontologisisku analīzi, pētot pašas spēles vai filozofiskus jautājumus, kas ir saistīti ar spēḷu dabu. Situacionistu pieeja pamatā analizē spēlētājus vai plašāku kultūru, pie kuras tie pieder. ${ }^{8}$ Śajā rakstā uzmanība videospēlēs tiek analizēta no formālistu perspektīvas.

Simone Haidbrinka (Simone Heidbrink), Tobiass Nols (Tobias Knoll) un Jans Visockis (Jan Visocki) definē divas pamata perspektīvas, pētot reliǵiju un videospēles: 1) spēles imanentā pieeja (game-immanent), kas nodarbojas ar visu spēles iekšèjo saturu un analizē reliğiskās tēmas un atsauces spēles kontekstā, pētot spēles ainu (gamescape); 2) uz spēlētāju balstīta pieeja (player-centered), kas koncentrējas uz spēlētājam pieejamu mijiedarbību spēles ietvaros. Šìs perspektīvas ir nevis izslēdzošas, bet papildinošas, un to izvēle ir atkarīga no pētnieka intereses. ${ }^{9}$ Raksta mērksis ir izpētīt dievišksības modelēšanas piemērus, kas ir atrodami dievspēles žanra videospēlēs, kuras sniedz spēlētājam iespēju iejusties dievības lomā. Sie dievišksības model̦i ir daḷa no spēles mehānikas un tās noteikumiem, līdz ar to pamatā tiks izmantota uz spēlētāju balstīta pieeja.

Spēles aina, kas ir pirmās perspektīvas fokusā, tiek veidota no sižeta un estētikas. Vairākumā spēḷu pastāv sižets. Tas var būt pasniegts caur spēles pamata sižetu, ko ir veidojuši autori, caur dal̦ām, kur spēlētājam ir iespējams to ietekmēt ar savu darbību vai izvēlēm, vai caur daḷām, kuras nav obligātas spēles galvenajam sižetam. Toties videospēḷu pētniecība nevar būt ierobežota ar naratīvo aspektu. Atšksirīibā no literatūras, teàtra vai kino, spēlētāji ir aktieri un lēmumu pieņēmēji spēlēs

7 Ernest W.Adams, What's Nextfor God Games?, http://www.designersnotebook.com/Lectures/God_Games/god_games.htm (skatīts 12.02.2018.)

8 Simon Egenfeldt-Nielsen, Jonas Heide Smith, Susana Pajares Tosca, Understanding Video Games: The Essential Introduction (New York: Routledge, 2008), 10-11.

9 Simone Heidbrink, Tobias Knoll, Jan Visocki, "Researching Religion, Digital Games and Gamers: (E)Merging Methodologies," in Digital Methodologies in the Sociology of Religion, ed. Sariya Cheruvallil-Contractor \& Suha Shakkour (London: Bloomsbury Academic, 2016), 159, 162. 
sižeta atklāšanas procesā. Tāpat spēḷu autori nestāsta stāstus vien - tie veido pasaules un telpu. Naratīvs saistībā ar vizuālo un skaņas dizainu piedalās telpiskuma un pasaules sajūtas veidošanā spēlētājiem - radot iegremdēšanās un citas pasaules sajūtu. ${ }^{10}$

Spēlu estētika daudzos gadījumos arī netiek paplašināti skaidrota. Tā ir fragmentāra un tiek veidota no alūzijām, kas balstās uz kultūras arhīvu vai kolektīvo atmiņu, kura veido dominējošo kultūras diskursīvo pavedienu kopumu. Tās izmanto pazīstamus vēsturiskus tēlus, attēlus, arhitektūru un citas vizuālās references, lai veidotu spēles pasaules estētiku. To iespējams definēt kā blīvo tekstu: kontekstu, atsauču, konotāciju kopumu, kas sniedzas pāri š̄ mediju žanra robežām un veido tēlu nozīmi. Tas notiek, pārceḷot mediju stāstījumu uz citiem medijiem. ${ }^{11}$

Piemērs šādam procesam var būt populārajā (ap 12000000 spēlētāju 2010. g., ap 5500000 spēlētāju 2017. g.) ${ }^{12}$ tiešsaistes spēlē World of Warcraft pastāvošā religinja "Svētās Gaismas baznīca" (Church of the Holy Light). Tās galva ir arhibīskaps, kuram ir bīskapu padome. Tajā kalpo priesteri, reliǵiskie karotāji un laicīgie locekḷi - neatkarīgi no dzimuma. Tai pieder klosteri, kas nodarbojas ar lauksaimniecību un peļnu ziedo nabagu vajadzībām. Tās absolūtā realitāte ir Gaisma, kas ir duālistisks pretstats Ēnai. Gaisma ir bezpersoniska dievišksāā realitāte, kas dod tās sekotājiem maǵiskās spējas dziedināt, stiprināt, aizsargāt un iznīcināt pretējā spēka, Ēnas, sekotāju maǵiju. Vēsturiski (spēlē atrodamajos radīšanas mītos) šīs baznīcas locekḷi ticēja "Dievam”, bet aktuālajā brīdī vairākums tās piekritēju nav teisti. Pastāv arī vairākās versijas par pasaules izcelsmi. Vizuāli tās estētika līdzinās Rietumu religisiskajai

${ }_{10}$ Simone Heidbrink, Tobias Knoll, Jan Visocki, "Researching Religion, Digital Games and Gamers: (E)Merging Methodologies," in Digital Methodologies in the Sociology of Religion, ed. Sariya Cheruvallil-Contractor \& Suha Shakkour (London: Bloomsbury Academic, 2016), 160.

11 Ibid, 161.

12 Estimated number of World of Warcraft subscribers from 2015 to 2023 (in millions), https://www.statista.com/statistics/276601/number-of-world-ofwarcraft-subscribers-by-quarter/ (skatits 12.02.2018.) 
arhitektūrai. ${ }^{13}$ Šìs religịjas tēls balstās uz globāli pazīstamu reliǵisku motīvu sapludināšanu, un tie ir ierakstīti spēles pasaulē un tai pārkārtoti.

Pētniecības koncentrēšanās uz spēlētāja iesaisti spēles ainās piedāvā citu analīzes veidu. Ir iespējams runāt nevis par spēles ainu, bet spēles pasauli (gameworld), kas sastāv no spēles ainas, mehānikas un visas potenciāli iespējamās komunikācijas un mijiedarbības starp spēlētāju un spēli. Šajā pasaulē notiek spēles spēlēšana jeb geimplejs (gameplay) - pastāv dažādi mijiedarbības līmeņi spēles procesā. Spēles pasaule un geimplejs veido "ludisko pieredzi". Piedaloties pasaulē, spēlētājs top par spēles pasaules daḷu. Relig̣ijpētniecībā iespējams aplūkot: a) spēlētājam sastopamās morālās izvēles un to religisisku interpretāciju vai motivāciju; b) spēles mehāniku (videospēles noteikumi), kas ietver reliǵiskās atsauces. ${ }^{14}$

Kopumā, lai analizētu spēles elementus, ir iespējams izmantot tās pašas metodes, kas ir pieejamas mākslas, mūzikas vai mediju pētniecībā. Vienīgais, ko šīs metodes nepārklāj, ir pati spēlēšana. Minētie autori piedāvā "spēlējošo pētniecību" (spēlēšanu kā metodi) - vienīgo veidu, kā ir iespējams izpētīt gan spēles saturu, gan mehāniku, gan arī spēlētāja iesaisti. Śāda pieeja balstās uz pārliecību, ka spēles un to veidotās realitātes mēdz būt atšksirīgas. Pastāv spēles, kas balstās uz notikumu attīstību un kas izaug no kāda neliela noteikumu klāsta, kas var dot vietu milzīgam apjomam iespējamo situāciju un iznākumu. Tās ir līdzīgas tradicionālām galda spēlēm. Otra kontinuuma puse ir progresijas spēles, kurās spēlētājam ir nepieciešams izpildīt noteiktu darbību kopumu, lai sasniegu spēles rezultātu, bieži ir iespējams tikai viens sižeta cel̦šs. Daudzas spēles mūsdienās ietver abus šos aspektus. ${ }^{15}$

${ }_{13}$ Church of the Holy Light, http://wowwiki.wikia.com/wiki/Church_of_ the_Holy_Light (skatits 12.02.2018.); God, http://wowwiki.wikia.com/ wiki/God (skatits 12.02.2018.)

14 Heidbrink, "Religion," 162-163.

15 Ibid., 164. 


\section{Religíija kā spēles mehānikas elements}

Gājienu stratēgijā Civilization VI spēlētāja mērķis ir vadīt vienu no valstīm (kas attēlo vēsturiskās civilizācijas), sākot no akmens laikmeta līdz tuvai nākotnei, sacenšoties ar citām. Civilizācijām piemīt unikālas īpašības. Katrā gājienā var veikt vairākas darbības līdzīgi tam, kā tas ir galda spēlēs. Tās mehānika ir ārkārtīgi plaša - tā modelē diplomātiskās attiecības, zinātnes un kultūras progresu, pasaules atklāšanu, tirdzniecību, spiegošanu, karu, pilsētu attīstību un arī religiju. Spēlētājs kontrolē visas savas civilizācijas resursus, ${ }^{16}$ pilsētas un vien̄̄bas (unit), lai sasniegtu uzvaru. Iespējamie uzvaras nosacījumi ir šādi: militāra, zinātniska, kulturāla, pēc punktiem un relig̣iskā. Uzvarēt iespējams, gan iekarojot visu civilizāciju galvaspilsētas, gan pirmajam dibinot koloniju uz Marsa, gan ar muzejiem un pasaules brīnumiem piesaistot visvairāk tūristu, gan arī pakḷaujot savai religijiai vairāk nekā 50\% katras civilizācijas pilsētu.

Tas notiek, vispirms ceḷot savās pilsētas svētvietas, kuras sniedz spēlētājam "Lielo Praviešu punktus". Tad ir iespējams radīt savu reliğiju (izvēloties vienu no 12 vēsturiskām piedāvātām religijāàm vai izveidojot savu). Tai neatkarīgi no izvēles var izraudzìt četrus ticējumus, kas sniegs noteiktus bonusus relig̣iju piekopjošai civilizācijai. Tāpat spēlētājam ir pieejams ticības resurss. To izmanto, lai veidotu religisiskās vienības, kuras lieto, lai relig̣iju izplatītu spēles pasaulē. Spēlētāja reliǵijai izplatoties, ticība pieaug. Šìs vienības var: a) pārvērst pilsētas; b) cīnīties pret pretinieku relig̣iskajām vienībām, piedaloties "teolog̣iskās batālijās". ${ }^{17}$ Atrodoties kara stāvoklī, ienaidnieku misionārus savā teritorijā iespējams sodīt ar nāvi. Savā teritorijā misionāri ir spēcīgāki, kā arī tuvu svētvietām. Tāpat ir iespējams pasludināt reliğisko karu, par kuru valsts nesaņem sodus par militārismu. ${ }^{18}$

16 Tie tiek pasniegti kā konkrētās civilizācijas (kultūra, ticība, zelts, zinātne, tūrisms) vai pilsētas (ēdiens, ražošana) "statistiskas vērtības".

${ }_{17}$ Civilization 6 - Theological Combat Explained, https://youtu.be/wC6OvEN6wgg (skatits 09.05.2018.)

18 Civilization VI In-Depth: Religion, https://youtu.be/WNFzIdbGKBU (skatīts 09.05.2018.) 
Civilization VI religijiai piemīt šādas iezīmes: a) relig̣ija ir valsts struktūras daḷa, tā kalpo tās interesēm; b) religijas būtībā ir relatīvas, un arī to saturs veidojas saskaņā ar valsts vajadzībām; c) reliğijas ir savstarpēji izslēdzošas, tikai viena var uzvarēt; d) relig̣iska uzvara ir simboliski nolikta vienā līmen̄̄ ar pārējām. Spēlētājam tiek piedāvāta nosacītā pāvesta-ķ̄ēniņa loma - ietekmēt religisku politiku, darīt to agresīvu vai piesardzīgu. Toties "evaņgelizēt" visu pasauli nav pienākums - var uzvarēt citādi, izmantojot religiju par atbalstu savai ekonomikai. Tāpat spēles brīvā rakstura dēḷ, atkārtoti spēlējot, ir atšksirīgi nosacìjumi - iespējams vienā brīdī saprast, ka, negribot zaudēt, nāksies izmantot agresīvo taktiku - iekarot pilsētas un izplatīt relig̣iju tajās vēlāk. Līdz ar to spēle parāda spēlētājam relig̣iju kā kultūras fenomenu, kura veidošanās ir neparedzama un nav esenciāli miermīlīga/agresīva, un ir dziļi saistīta ar valsts struktūru. Tāpat spēle neuzdod jautājumu par transcendento, bet vērš uzmanību uz reliǵijas funkcionālo aspektu.

Left Behind 3: Rise of the Antichrist pieder pie kristīgo spēlu žanra. Tā ir reāllaika stratēg̣ija (atšksirībā no Civilization VI, notikumi risinās pasaulē, kur viss notiek nepārtraukti), kuras notikumi risinās N̦ujorkā pēc paraušanas, - premileniāra dispensionālisma teologijas izpratnē, kur starp ticīgo paraušanu debesīs un Kristus otro atnākšanu septinuus gadus notiek lielās bēdas. ${ }^{19}$ Tās sižets ir pamatojas uz ASV evaņğelikāḷu atbalstīto grāmatu sēriju ar identisku nosaukumu. Spēlētājs kontrolē kristiešu grupu, kas cīnās pret antikristu, kurš ir izveidojis pasaules valdību. Mērķis ir pievērst Ņujorkas iedzīvotājus kristietībai. Ir iespējams arī nogalināt antikrista piekritējus, toties tas pazemina spēlētāja pārvaldīto vienību gara spēku, kuram izbeidzoties spēle tiek zaudēta. Funkcijas "lūgt" un "garīgā vadība" vai "kristīgā mūzika" atgriež zaudēto gara spēku. Tāpat ir iespējams spēlēt antikrista pusē, darot to pašu (lūgšanu vietā launie tēli lamājas, garīgās vadības - zaimo); vai ASV zemessardzes pusē, kas nevar konvertēt, bet tikai nogalināt. Pamata sižets tomēr vērsts uz kristiešu uzvaru. Spēlētājs kontrolē kristiešus vai antikrista sekotājus, kas atšksiras pēc izskata, bet pēc būtības dara to pašu un tiek kontrolēti līdzīgi.

19 "Dispensationalism," in Daniel Patte, ed., The Cambridge Dictionary of Christianity (Cambridge: Cambridge University Press, 2010), 328. 
No vienas puses, konversija risinās ḷoti vienkāršoti - nostādot spēlētājam piederīgu vienību blakus neitrālam iedzīvotājam un pielietojot viņam funkciju "pievērst". No otras puses, katram iedzīvotājam ir pievienots unikāls dzīves stāsts, kaut arī tas neietekmē spēles procesu. Pēc tam konvertēto var mācīt apgūt kādu profesiju, kas stimulēs Kristus vai antikrista sekotāju veiksmi. ${ }^{20}$

Šìs spēles mehānika visumā ir līdzīga daudzām dievspēles žanra spēlēm. Gara punkti ir analogiiski ticības parametram citās spēlēs. Spēlētājs izmanto tos, lai veiktu religisiskās darbības spēles pasaulē, atklājot dievības spējas ietekmēt pasauli. Spēlē Left Behind šiem punktiem izbeidzoties, spēlētājs zaudē. Tas notiek tādēl, ka spēlētājs kontrolē sekotājus, nevis pašu Dievu. Izbeidzoties sekotāju Gara punktiem, zūd arī to spējas izplatīt kristietību un spēja uzvarēt. ${ }^{21}$

Kevins Šats (Kevin Schut) min šīs spēles par piemēru relig̣ijas mehanizācijai videospēlēs. Viņš kritizē ticības formulēšanu skaitliskajā izteiksmē, ko nav iespējams veikt ārpus simulācijas, fiziskajā pasaulē. Tās, viņaprāt, arī reprezentē teolog̣iju, kurā nav vietas neparedzamai dievības rīcībai. Dievības mistērija un nesaprotamā daba nevar būt izteiktas spēles noteikumos. Šats iestājās par spēlēm, kas demehanizē relig̣iju caur sižetu, attēlojot reliğiskās pieredzes sarežgitto raksturu. Toties viņš atzīst, ka spēles noteikumi, kas veido spēles robežas, nevalda pār spēlētāju iztēli un spēju uzspiest spēlei savu naratīvu. ${ }^{22}$

\section{Klasiskais dievspēles veids}

1989. gadā radītā spēle Populous tiek uzskatīta par pirmo spēli dievspēles žanrā. ${ }^{23}$ Tajā spēlētājs-dievs (ar brīvi izvēlēto vārdu) vada sekotāju tautu uzvarā pār citām tautām, kuras

20 Left Behind 3 Rise of the Antichrist review - ChristCenteredGamer.com, https://youtu.be/4nUKtFTM01o (skatīts 09.05.2018.)

${ }_{21}$ Antikrista sekotājiem ir jāpazemina šie paši punkti, lai spētu rīkoties, un maksimālā "Gara" punktu skaita sasniegšana liek tiem zaudēt.

22 Kevin Schut, "They Kill Mystery," in Playing With Religion in Digital Games, ed. Heidi A. Campbell \& Gregory P. Grieve (Bloomington: Indiana University Press, 2014), 258, 261-264, 272-273.

2350 Greatest Game Design Innovations, https://web.archive.org/web/ 20100924064303/http://www.next-gen.biz/features/50-greatest-game-design-innovations?page $=0 \% 2 \mathrm{C} 3$ (skatits 11.07.2018.) 
tāpat vada viņu dievi. Spēlētājs-dievs var: 1) paaugstināt vai pazemināt ainavas līmeni, lai l̦autu sekotājiem izplatīties un uzcelt jaunus mājokḷus; 2) uzsūtīt ienaidniekiem maǵiskus stihijas spēkus, lai veicinātu savas tautas izplatīšanās ceḷu. Dievība nevar kontrolēt sekotājus tiešā veidā, bet var radīt apstākḷus to labklājībai. Tāpat tikai sekotāji, kuri ir sasnieguši pietiekami lielu skaitu un ir spēlētāja-dieva pieskatīti, var pievārēt pretinieku tautu. Spēlētājs var noteikt sekotāju uzvedību (karot vai celt pilsētu). Sekotāju daudzums palielina spēlētāja "manas" apjomu - jo vairāk ir "manu", jo lielāka ir spēlētāja pārdabiskā ietekme uz pasauli. ${ }^{24}$ Populous 2, kas tika izdota 1991. gadā, lielākoties atkārtoja pirmās spēles principus, paplašinot dievu ietekmes iespējas. ${ }^{25}$

Populous sērijas spēlēs spēlētājs-dievs var ietekmēt tikai savu sekotāju darbības virzienu. Tā ir netiešā kontrole. Citādi sekotāji spēj rīkoties un attīstīt savu tautu un tās pilsētu patstāvīgi. Dievības iejaukšanās ir nepieciešama, lai atbrīvotu vietu sekotāju mītnēm un atbalstītu tos karā pret svešo cilti. Veiksmīgs atbalsts ietekmē arī dievības spējas, jo lielākais sekotāju skaits palielina spēlētāja manu. "Mana" Populous sērijā līdzinās ticības punktiem vēlākajās dievspēlēs, parādot gan dievības iespējas ietekmēt pasauli, gan viņa sekotāju kvalitāti, Populous gadījumā - skaitu.

ActRaiser (1990) ir dievspēle ar platformas spēles elementiem. Spēlētājs-dievs jeb Pavēlnieks (The Master) spēles pasaulē cīnās pret Tanzru jeb Ľauno, dēmonu valdnieku, kas ir pārņēmis pasauli. Dievs cel̦o pa pasauli "debesu pil̄̄”. Pirms kāda teritorija paliek atvērta sekotāju apdzīvošanai, dievam tā ir jāattīra no briesmoņiem. Viņšs sūta atdzīvinātu statuju ar zobenu, kuru kontrolē spēlētājs. ${ }^{26}$ Ierodoties iedzīvotājiem, spēlētājs-dievs norāda tiem pilsētas celtniecības virzienu un palīdz ar maǵiskām darbībām, piemēram, aplaistot ražu ar lietu. Pilsētas pārvaldes režīmā spēlētājs kontrolē eņgeli, kas lido virs pilsētas un īsteno pavēles. Tāpat eņgelis var ar bultām atvairīt mošksus, kas lien ārā no mošksu bedrēm ap to. Sekotāju

${ }_{24}$ Populous (PC), https://youtu.be/u6hHkmn3DI0 (skatīts 11.07.2018.)

25 Populous 2: Trials Of The Olypian Gods (SNES) - Gameplay, https://youtu.be/g9HL73MeRMQ (skatīts 11.07.2018.)

${ }_{26}$ Šajā brīdī spēlē pāriet platformas spēles režīmā. 
civilizācijai augot un izplatoties visā spēles pasaulē, aug arī spēlētāja-dieva spējas veikt brīnumus vai viņa avatāru (eņgela un statujas) dzīvības punktu apjoms. ${ }^{27}$

Spēlē ActRaiser spēlētājs var kontrolēt savus sekotājus stingrāk nekā Populous sērijas spēlēs, kur tie automātiski izplatās visur, kur dievs atbrīvo teritoriju. Dievam ir vara pār pilsētas plānošanu, un viņa sekotājiem nav ticības parametra. Toties arī spēlē ActRaiser spēlētājs-dievs tiešā veidā kontrolē tikai dievības avatāras. Dieva līmenis, kas nosaka spēlētāja spējas, ir atkarīgs no sekotāju skaita. Sekotāju civilizācijas celšana līdz ar to ir cieši saistīta ar dievības spēka atgriešanu, kas ir nepieciešama soterioloğiskajiem mērksiem.

Spēlē Afterlife (1996) spēlētājs-dievs ir demiurgs, kurš pārvalda kādas planētas pēcnāvi (Afterlife). Tā ir realitāte, kur atrodas šìs planētas elle un paradīze. Spēlētājam ir jāpārvalda un jāattīsta gan elle, gan paradīze atbilstoši mirušo dvēselı plūsmai. Ellē dvēselēm tiek iedalītas soda vietas saskaņā ar septiņiem nāves grēkiem, paradīzē - saskaņā ar septiņiem atbilstošiem tikumiem. Mirušo dvēseles pēcnāvē uzvedas atbilstoši savai reliǵiozitātei. ${ }^{28}$ Ja spēlētājs nespēj organizēt pietiekami daudz vietu visām dvēselēm, tās tiek zaudētas un demiurgs zaudē līdzekḷus. Ik pa laikam uz nenosauktās planētas notiek katastrofas, kas liek plūsmai strauji pastiprināties. Tāpat dvēseles, kas paliek pēcnāvē, mūžīgi ir iespējams apmācīt par dēmoniem vai eñgeliem, kas strādās spēlētāja pēcnāvē, pazeminot izmaksas darbinieku algošanai. ${ }^{29}$

Liela dạ̦a Afterlife mehānikas ir raksturīga ekonomiskās stratēgijas spēles žanram, piemēram, restorāna vai pilsētas pārvaldes spēlei. "Dievspēḷu" kontekstā Afterlife izcel̦as ar vienlaicīgu kontroli pār elli un paradīzi, kā arī ar mērksi pārvaldīt mirušos, nevis dzīvos. Demiurgam nav varas pār dvēseḷu plūsmu un atbildības par dvēsel̦u nonākšanu ellē vai paradīzē,

${ }^{27}$ SNES Longplay [056] ActRaiser, https://youtu.be/Tmm0R5mJJzA (skatìts 11.07.2018.)

${ }_{28}$ Dvēseles "religiozitāti" nosaka šīs izvēles: 1) pārliecība par elli vai paradīzi kopumā - vai jāiziet abas vai tikai viena, vai arī pastāv tikai viena no tām; 2) mūžìgais stāvoklis pēcnāvē vai reinkarnācija; 3) sods/atalgojums par visiem grēkiem vai tikai par galveno.

29 Let's Play Afterlife - 1 (Tutorials), https://youtu.be/FvL2FW2btXg (skatīts 09.05.2018.) 
kā arī par viņu reliǵiozitāti. Spēlētājam ir tikai spējas uzturēt pēcnāves realitāti atbilstoši planētas mirušo dvēseḷu pieprasījumam.

Spēlē Dungeon Keeper (1997) spēlētājam ir jāvada un jāattīsta briesmoņu pazemes midzenis, kuram uzbrūk varoņi. Spēlētājs kontrolē midzeņa celtniecību pilnībā, bet, lai viņa vadītie briesmoņi funkcionētu efektīvi, tiem ir jānodrošina ēdiens, izklaides un alga. Tāpat daži briesmoņi, kurus iespējams iemitināt midzen̄̄, nevar sadzīvot savā starpā un var sacelt nemierus. Spēlētājs nevar pavēlēt briesmoņiem tiešā veidā, bet var tos pārcelt vai sodīt “ar roku”. Lai veiktu maǵiskās darbības, tiek izmantots zelts, kuru vāc spēlētāja celtnieki. ${ }^{30}$

Līdzīgi citām dievspēlēm Dungeon Keeper spēlētāja veiksme ir atkarīga no pareizo apstākḷu veidošanas saviem sekotājiem jeb no sadarbības starp (šajā gadījumā - launo) dievību un tiem. Tikai sekotāji var sasniegt spēles mērķi, tikai ar spēlētāja palīdzību. Šajā spēlē nepastāv ticības parametrs, bet demonisku sekotāju uzticība ir atkarīga no to vajadzību un îpatnību ievērošanas.

Spēle Black \& White (2001) (Black \& White 2 izdota 2009. g.) ir reāllaika stratēgija. Grieķu ciltij, kas mìt nenosauktajā pasaulē, uzbrūk acteku cilts un iznīcina viņu pilsētu. Spēlētājs parādās pasaule kā dievs, kuru grieķu cilts aicina ar tīro lūgšanu no nebūtības. Spēlētājam ir jāizglābj noteikts cilvēku skaits, un tie pārceḷas citā realitātē, kur dievs palīdz šai ciltij attīstīties. Spēlētājs kontrolē šì dieva darbības izpausmes ar kursoru ekrānā, kas ir veidots rokas formā, ar kuru var pārcelt cilvēkus, objektus un citādi ietekmēt pasauli. Sekotāji izvēlas sev nodarbes paši, bet dievība var tos ielikt spēlētājam vajadzīgajā vietā (uz lauka, templī utt.). Tāpat dievam ir manifestācija dzīvnieka formā, kas pilda viņa pavēles. Dievs var veikt brīnumus (uguns, vairogs, dziedināšana utt.). Spējas ir ierobežotas ar lūgšanas spēku vai "manu", kas palielinās sekotāju lūgšanu vai to upurēšanas dēḷ. Spēlētājs var būt labais dievs, koncentrējoties uz cilts labklājību, aizsargājot citas pilsētas un miermīlīgi tās pievēršot savai reliǵijai. Ļaunais dievs karo, upurē savus iedzīvotājus (jaunieši sniedz lielāku bonusu),

30 Dungeon Keeper - Gameplay, https://youtu.be/wLzBb2BToZI (skatīts 11.08.2018.) 
iebiedē tos ar agresīviem brīnumiem, svaida tos apkārt utt. Iespējams "dresēt" savu manifestāciju, lai arī tā būtu l̦auna vai laba. Tāpat šìs rīcības dēl mainās templis, kas ir uzcelts spēlētājam-dievam - vai nu balts un gluds, vai tumšs un dzelkšņains, arī attiecīgi naktis paliek garākas un debess pa dienu kḷūst tumšāka, un otrādi. Neatkarīgi no labā/lıaunā izvēles spēlētājam ir ienaidnieks-dievs, kuru pievarot spēlētājs kḷūst par vien̄̄go dievu tajā universā (Black and White) vai nosargā savu cilti (Black \& White 2). ${ }^{31}$

Spēlē Black and White vienas ētiskās izvēles pieņemšana netiek uzskatīta par uzvaras nosacījumu. Ir iespējams arī būt neitrālam, rīkojoties gan labi, gan l̦auni, kaut arī tas vizuāli ietekmēs spēlētāja cilti, pilsētas un spēles principu. Svarīga ir dieva veiksme - rīkojoties prātīgi, labi vai l̦auni, dievs iegūs savu sekotāju maksimālo atbalstu un uzvarēs pretinieku cilti. Zaudējot ticīgo atbalstu, dievs zaudē spēju ietekmēt pasauli un kḷūt par visu cilšu dievu.

Spēle Heaven \& Hell (2003) ir reāllaika stratēgija, kurā spēlētājs izvēlas labo vai l̦auno dievu. Mērksis ir uzvarēt dievu-oponentu, pievēršot sev ciematus, kurus apdzīvo viņa sekotāji vai neticīgie. Līdzīgi kā spēlē Black \& White, saskaņā ar sekotāju pārliecības maiṇu mainās arī viņu drēbju un mītņu izskats. Sekotāji nav pakḷauti dievības kontrolei, bet spēlētājs var norīkot no viņu vidus praviešus, kas pilda spēlētāja-dieva pavēles: pievērš savai relig̣ijai iedzīvotājus, māca karavīrus, zog pretiniekam "manu" utt. Sekotājiem piemīt ticības parametrs - tikai sasniedzot noteiktu līmeni, tie pievēršas spēlētāja reliǵijai. Ticību palielina spēlētāja praviešu veiktie brīnumi. Pievērstie sekotāji generē "manas” punktus, kurus spēlētājs izmanto, lai veiktu brīnumus un attīstītu pievērstos ciemus. Lُaunā un labā dieva spējas ir identiskas, atšksiras viņu nosaukums un izskats. Ļaunā mērksis ir iznīcināt pasauli, labā mērksis - to izglābt..$^{22}$

${ }^{31}$ Black \& White 1 HD - God Game 2001! - Download \& Gameplay on Windows 10 - [Abandonware Adventures!], https://youtu.be/JuScYpFqiEg (skatīts 09.05.2018.); Black \& White 2 | Let's Play \#1 | Meet Buttercup, https://youtu.be/Ue4i44e_7W8 (skatits 09.05.2018.)

${ }^{32}$ Heaven and Hell - Good Campaign - Mission One, https://youtu.be/ mvYVsjSDK8s (skatīts 25.07.2018.) 
Spēlē Heaven \& Hell spēlētājs-dievs ietekmē pasauli ar savu praviešu palīdzību. Tie nāk no sekotāju vidus un ir kontrolēti tiešā veidā. Pārējie sekotāji generē spēlētāja "manas" punktus un citādi ir autonomi un pasīvi. Kaut arī dievība var veikt brīnumus bez praviešu starpniecības, tikai pravieši var sasniegt spēles uzvaras nosacījumus - pievēršot savai relig̣ijai iedzīvotājus un pārvarot pretinieka praviešu centienus sasniegt to pašu.

Spēle From Dust (2011) līdzīgi vairākumam spēlu žanrā ir reāllaika stratēgijija. ${ }^{33}$ Arī šeit spēlētājam-dievam tiek uzticēts viņa sekotāju cilts liktenis un to vadīšana. Šìs spēles dievība tiek pasniegta kā "dvaša”, kuru cilts piesauc, izpildot rituālo mūziku. "Dvaša" palīdz cilvēkiem "sarunāties" ar pasauli - savaldīt haotiskus spēkus (ūdeni, vulkānus, uguni) un norāda tiem ceḷu. Tā arī piešksir ciltij spēkus, kas palīdz savaldīt dabu. Cilts mērķis ir atrast "Senos", kas ir devušies caur šo pasauli pirms viņiem. Veicot rituālus, cilts cel̦ ciemus pie "Seno" totēmiem un veicina augu izplatīšanos pasaulē..$^{34}$

Spēles From Dust spēlētājs-dievs var kontaktēties ar matēriju un pārcelt to no vietas vietā, pārveidojot pasaules ainu. Tāpat "dvaša” norāda sekotājiem virzienu, bet nevar kontrolēt tos tiešā veidā. Ja tiem kas draud, tā ir spiesta palīdzēt ar matērijas kustināšanu (piem., paberot smilšu kalnu zem slīkstošā sekotāja). Spēlētāja pavēles tiek pildītas bez ierunām, ikviens "dvašas" sekotājs pilda tās pat nāves briesmu priekšā. To neietekmē kāds ticības parametrs. Līdz ar to spēlētājs-dievs kontrolē kādu neskaidras izcelsmes radošo spēku.

Spēlē Reus (2013) spēlētājs-dievs pārvalda pasauli un rūpējas par cilvēkiem, kontrolējot dabas procesus. Spēlētājs var kādā planētas daḷā mainīt ainavas tipu (tuksnesis, okeāns, mežs, purvs) vai izveidot tajā kādu sekotājiem vajadzīgo resursu (ogas, dzīvniekus, minerālus utt.). Spēlētājs kontrolē milžus, kas reprezentē pirmatnējās stihijas spēkus. Tie veic dažādas darbības, kā arī attīsta jau izvietoto resursu ieguvi. Resursi piesaista sekotājus, un tie dibina pilsētas to apkārtnē.

${ }_{33}$ From Dust, https://store.steampowered.com/app/33460/From_Dust/ (skatìts 11.08.2018.)

${ }^{34}$ From Dust Walkthrough-Part 1 XBLA(Gameplay \& Impressions), https:// youtu.be/h5B1wHhhK7c (skatīts 11.08.2018.) 
Sekotāju pilsētu attīstība ir atkarīga no šo darbību veiksmes. Kombinējot atšksirīgus resursus un apmierinot sekotāju vajadzības, dievība veicina sekotāju izplatīšanos planētā. Bet, ja attīstība nenotiek vai ir pārāk strauja, sekotāju pilsētām pieaug alkatības parametrs, kas liek tiem uzsākt karu pret citām pilsētām. ${ }^{35}$

Spēle Reus līdzinās citām dievspēlēm netiešās kontroles īstenošanā. Vides (dabas) attīstība vai iznīcināšana ir vienīgais sekotāju atbalsta veids. Šai spēlē nepastāv ticības parametrs un spēlētāja darbības ir ierobežotas nevis ar kādu kvantitatīvu parametru, bet ar planētas robežām un tajā jau izveidoto biosfēru. Toties sekotāju stāvoklis (alkatības parametrs) ietekmē viņus pašus - uzsākot karu, tie pārstāj attīstīt pilsētu un spēj iznīcināt arī citas pilsētas, graujot spēlētāja-dievības veidoto sistēmu.

Spēle Crest (2018) ir reāllaika stratēg̣ija. ${ }^{36}$ Tajā, līdzīgi citām rakstā aplūkotām spēlēm, spēlētājam dieva lomā ir jārūpējas par sekotāju cilti. Tā vāc resursus, dzemdē pēcnācējus, dibina jaunās pilsētas. Šìs spēles mehānikas pamatā, atšksirībā no citām žanra spēlēm, ir netiešā kontrole. Spēlētājs-dievs nevar ietekmēt savas darbības pasauli - ne ainavu, ne vien⿳亠bas. Kontrole tiek īstenota, dodot sekotājiem "baušlusus", piemēram, vārdi "sekotāji, kas dzīvo džungḷos" ar vārdiem "vākt" un "ogas" mudina sekotājus vākt ogas. Ar laiku cilts iemācās jaunus vārdus. Baušliem ir iedarbības ilgums, un sekotāji var tos arī ignorēt tādēl, ka tie nesakrīt ar viņu pārliecību vai situāciju. Pilsētām piemīt "doktrīna”, kas nosaka viņu intereses un reakciju uz baušlıiem; kad reakcija ir negatīva, pilsētas izveido savas interpretācijas baušliem. Slikto apstākḷu dēḷ cilts spēj nonākt līdz kanibālismam. Spēlētājam-dievam ir iespēja nolādēt vai svētīt sekotāju radītās interpretācijas. Nolādējot tiek pazemināta pilsētnieku ticība, svētot - paaugstināta. Tāpat pilsētas karo savā starpā atšksirīgu interpretāciju dēḷ. ${ }^{37}$

35 Reus - God Game of Ancient Giants, https://youtu.be/giDFdSjvMwo (skatits 11.08.2018.)

${ }^{36}$ Crest - an indirect god sim, https://store.steampowered.com/app/341710/ Crest__an_indirect_god_sim/ (skatīts 11.08.2018.)

${ }_{37}$ Tribal Survival and Hippo Rampage! - Let's Play Crest Gameplay, https://youtu.be/hBRDcWH3xYA (skatits 11.08.2018.) 
Spēlē Crest, iepretī Black \& White sērijai līdzīgām spēlēm, kur spēlētājs-dievs var kontaktēt ar pasauli burtiski "ar roku", tiek modelēta dievība, kas spēj tikai vērot notiekošo un mēgìna dot pareizās pavēles cilvēkiem. Tāpat tiek modelēta sekotāju brīvā griba, kas padara tos neatkarīgus arī no dievības pavēlēm gadījumos, kad sekotāji tām nepiekrīt. Šajā modelī dievība nekontrolē pasauli, bet uzrunā savus sekotājus, aicinot tos attīstìt savu kultūru, nenodoties vardarbībai un neiznīkt. Šajā spēlē dievības veiksme tiek mērīta ar tās cilts izdzīvošanu un spēju dot sekotājiem tai nepieciešamos "baušlus", kā arī apturēt to patvaḷigās interpretācijas, kas draud iznīcināt cilts labklājību. Veiksme ḷauj saglabāt sekotāju ticību, kas izsaka viṇu gatavību sekot dievības pavēlēm.

\section{Citu žanru "dievi"}

Patapon (2007) ${ }^{38}$ ir ritma spēle, kurā pataponu cilts dievs vada tos viņu leg̉endārajā ceḷojumā uz pasaules malu. Dievs komunicē ar cilti un vada to ar sakrālo kara bungu starpniecību. Spēlētājs spiež pogas, veidojot vienu no iespējamajiem ritmiskiem attēliem, kas atbilst kādai pavēlei. Spēles sākumā cilts atpazīst dievību pēc rituālo bungu skaņas un paklausa tai tikai tad, kad spēlētājs uztur pareizo ritmu. Bez dievišķāa ritma cilts nevar uzvarēt savus ienaidniekus. ${ }^{39}$ Līdzīgi klasiskām dievspēlēm, veiksme veidojas, dievībai sadarbojoties ar sekotājiem, kaut arī šajā spēlē sekotāji nedarbojas autonomi, bet, radot ritmu, spēlētājs rada nepieciešamos nosacījumus to uzvarai.

Loğikas spēlē Doodle God (2010) spēlētājs dieva lomā kombinē dažādus dabas elementus, lai no tiem izveidotu jaunus. Spēle sākas ar četru klasisku elementu savienojumiem (uguns, ūdens, zeme, gaiss), no kuriem tiek atklāti jauni. Spēlētājam ir jāturpina kombinēt elementi, kamēr tiks atklāti visi. Elementu starpā mēdz būt arī instrumenti un dzìvnieki. Dievībai atklājot jaunus elementus, tie parādās arī uz dievības pārvaldītās

${ }_{38}$ Patapon PSP, https://www.gamepressure.com/games/patapon/z6201c (skatīts 19.07.2018.)

39 Let's Play - Patapon (PSP) - Part 1, https://youtu.be/yHrZKi0wpaQ (skatìts 19.07.2018.) 
planētas attēla. ${ }^{40}$ Šajā spēlē dievībai nav sekotāju, bet ir tikai ietekme uz pasaules radīšanu. Tāpat dievība nav omnipotenta radīšanas procesā. Tā atklāj jaunus elementus atkarībā no jau esošajiem.

Godville (2010) ir pieteikta kā bezspēlētāja spēle (zero-player game). ${ }^{41}$ Spēles sākumā spēlētājs izveido dievību un varoni, dodot tiem vārdus un izvēloties dzimumu. Spēlētājs kontrolē dievību, bet varonis pats par sevi cīnās ar ienaidniekiem, meklē artefaktus un attīsta savas spējas. Par viņa situāciju spēlētājs-dievs uzzina no teksta loga. Dievība var ietekmēt varoni, izmantojot dažas vienkāršas pavēles, atlīdzinot par pūlēm vai sodot viņu par nepaklausību. Tāpat tā var aicināt varoni lūgt, tas atjauno punktus, kas nepieciešami, lai pavēlētu. Ja dievība soda varoni pārāk bieži, tas pārstāj lūgt un dievība zaudē varu pār viņu. ${ }^{42}$ Šìs spēles dievība ir gandrīz pilnībā atdalīta no varoņa, tās vienīgā sekotāja. Varonis var dzīvot un attīstīties bez tās palīdzības, pat zaudējot ticību. Sekotājs ir pilnīgi autonoms no dievības.

Spēlē Pocket God (2012) dievība pārvalda salu, kur mīt maza pigmeju cilts. Spēlētājs kontrolē laika apstākḷus, gravitāciju, priekšmetu parādīšanos salā, dzīvniekus, kā arī pārvieto pašus cilts iedzīvotājus un maǵiski ietekmē tos. Spēles mērķis ir dažādos veidos mocīt un iznīcināt cilts iedzīvotājus. Tos ir iespējams atjaunot, nospiežot pogu. Cilts iedzīvotājus nevar kontrolēt tiešā veidā, bet tie reağè uz spēlētāja darbībām. ${ }^{43}$ Spēlē Pocket God, iepretī vairumam dievspēḷu, dievības darbība tiek ierobežota destruktīvajā aspektā. Toties tā līdzinās klasiskai dievspēlei netiešas kontroles aspektā.

\section{Secinājumi: dieviškš̄ības modelis dievspēlēs}

Dievspēlēm piemīt vairākas kopīgas raksturīgas īpašìbas, kuras veido dievspēḷu dievišksības modeli. Pirmkārt, līdzīgi citām spēlēm, kurās reliğijas ir daḷa no spēles mehānikas,

40 What do I need to make next? - Doodle God \#1, https://youtu.be/ m2xZjVsmHdg (skatits 19.07.2018.)

${ }^{41}$ Ar to tiek domāta spēles varoṇa automatizētā darbība.

${ }_{42}$ Godville, https://godvillegame.com (skatīts 19.07.2018.)

${ }_{43}$ [Android] Pocket God, https://youtu.be/BqDeWbnbVnU (skatīts 19.07.2018.) 
vairākumā dievspēḷu vienā vai citā veidā dievišksā spēka resurss ir atkarīgs no spēlētāja-dieva sekotāju stāvokḷa - viņu labklājības atkarībā no konkrētas spēles noteikumiem. Tas tiek izteikts ar ticības vai tiem analogiskiem "manas" punktiem, kurus generē sekotāji. Vairākumā spēḷu tas ir atkarīgs no sekotāju skaita. Otrkārt, vairākumā spēlı attiecības starp dievību un sekotājiem tiek netieši kontrolētas. Virtuālie sekotāji imitē mākslīgo dzīvi, bet spēlētājs-dievs kontrolē to no ārpuses. Daudzās spēlēs netiešā kontrole ir nomināla un spēlētājam-dievībai ir iespējas precīzi norādīt sekotājiem darbības virzienu. Toties šì atšķirība starp sekotājiem un dievību tiek izteikti pasvītrota. Treškārt, praktiski visās dievspēlēs galvenais izaicinājums spēlētājam ir veiksmīgi izmantot dievībai pieejamus spēkus, lai veicinātu sekotāju progresu, kura būtība mainās atkarībā no spēles.

Padarot dievību par atkarīgu no sekotāju ticības apjoma un no veiksmīgas sadarbības ar tiem, dievspēles attēlo dievišksību kā atšķirīgu, bet nedalāmi saistītu ar cilvēku, galvenokārt pozitīvi saistītu. Savukārt ticības parametra lietojumu dievspēlēs var saprast kā refleksiju par religisku uzplaukumu un norietu. Piemēram, dievspēḷu interpretācijā vēsturiskai asīriešu religijai vairs nav piekritēju, tās dievībām nav ticības punktu un līdz ar to spējas ietekmēt mūsu pasauli. Tāpat "baušlı̆u" padarīšana par daḷu no spēles mehānikas (kurā sekotāji tos interpretē un pārprot) ir refleksija par sakrālo tekstu interpretāciju un reinterpretāciju pasaules reliǵijās gadsimtu gaitā. Vairākuma dievspēḷu izaicinājums - izveidot veiksmīgu jeb laimīgu sekotāju civilizāciju - pats par sevi ir apgalvojums par religijijas nozīmi un vērtību pasaules vēsturē.

Dievspēles iespējams kritizēt par daudzpusīgu religisisku jēdzienu (ticība, sekošana, baušli) mehanizāciju spēles noteikumu veidošanas procesā. Toties mehanizācija tiek veikta apzināti, veidojot spēles noteikumus. Tas neliedz dievspēlēm reflektēt par reliğiskām norisēm. Spēles noteikumi izsaka apgalvojumus par tradicionālo reliǵisku kategoriju nozīmi, veidojot dievišksības un reliǵiozitātes model̦us spēles pasaulē. Toties šīs kategorijas saglabājas refleksijas pamatā, un tas ḷauj dievspēles nolikt blakus citu modernu mediju refleksijai par reliǵgisko, garīgo un dieviškso. 


\section{Summary}

\section{Playing God: the God-game Videogame Genre according to the Player-centered Approach}

The paper analyzes the model of divinity in the god-game videogame genre in the light of the player-centered approach. The player-centered approach focuses on the available interaction between a player and the gameworld. The challenge that god-games offer to a player is to be a god for a certain world or a group of followers. The success of a player-god depends on collaboration with its followers. The model of divinity consists of religious references found in the rules of the game. Traditional religious categories are adapted to the game rules. 